\title{
HASIL PEMBANGUNAN OLAHRAGA DI KOTA JAMBI DITINJAU DARI SPORT DEVELOPMENT INDEX
}

\author{
Sukendro Dasar ${ }^{1 *}$, Grafitte Decheline ${ }^{2}$ \\ ${ }^{1}$ Universitas Jambi \\ email : grafittedecheline10184@gmail.com
}

\begin{abstract}
Abstrak
Penelitian ini dilatarbelakangi permasalahan yaitu belum diketahuinya pembangunan olahraga Kota Jambi ditinjau dari Sport Development Index (SDI). Keempat aspek SDI akan membantu menilai proses pembangunan olahraga di Kota Jambi dari tahun ke tahun yang selanjutnya akan mempengaruhi pengukuran indeks pembangunan olahraga di daerah. Tujuan penelitian ini adalah 1) untuk mengetahui ketersediaan ruang terbuka olahraga di Kota Jambi 2) mengetahui kuantitas dan kualitas sumber daya manusia keolahragaan di Kota Jambi, 3) mengetahui tingkat partisipasi masyarakat di Kota Jambi dan 4) mengetahui tingkat kebugaran jasmani yang dimiliki masyarakat di Kota Jambi. Penelitian ini termasuk dalam jenis penelitian kuantitatif. Penelitian ini juga mengevaluasi kebijakan pemerintah terkait pembangunan olahraga tentang Standar Pelayanan Minimal Keolahragaan, sehingga penelitian ini juga termasuk penelitian evaluatif. Sampel penelitian berjumlah 270 orang dari 3 kecamatan. Teknik pengambilan sampel dengan cluster sampling. Instrumen yang digunakan berupa angket dan serangkaian protokol Multi Stage Fitness Test untuk mengetes kebugaran jasmani masyarakat. Hasil penelitian ini adalah (1) indeks ruang terbuka Kota Jambi adalah 0,364, lebih tinggi dibandingkan nilai indeks ruang terbuka nasional $(0,266),(2)$ indeks Sumber Daya Manusia keolahragaan Kota Jambi adalah 0.00057, sangat jauh dibawah indeks SDM nasional $(0,099)$, (3) indeks partisipasi masyarakat Kota Jambi 0,57, lebih tinggi dari indeks partisipasi nasional $(0,422)$, (4) indeks kebugaran jasmani Kota Jambi yaitu 0,340, lebih tinggi daripada indeks kebugaran nasional $(0,335), 5)$ indeks pembangunan olahraga (SDI) Kota Jambi yaitu 0,318. Kesimpulan penelitian ini adalah indeks SDI Kota Jambi masih berada pada kategori rendah karena indeks total SDI yang meliputi Ruang Terbuka, Sumber Daya Manusia, Partisipasi Olahraga dan Kebugaran Jasmani masyarakat Kota Jambi sebesar 0,318 berada direntang 0-0,499. Artinya bahwa pembangunan olahraga kota Jambi masih perlu diperhatikan dan dibenahi oleh pemerintah kota untuk memajukan olahraga di kota Jambi.
\end{abstract}

Kata kunci: Sport Development Index, Ruang Terbuka, Sumber Daya

Manusia, Partisipasi Olahraga \& Kebugaran Jasmani

\begin{abstract}
This research is motivated by the undetermined sports development in Jambi City Jambi Province in terms of Sport Development Index (SDI). This study aims to determine 1) the availability of sport open space in the Jambi city 2) the quantity and quality of human resources of sports in the Jambi city, 3) the level of community participation in the exercise in the Jambi city and 4) the level of physical fitness of people in the Jambi city. This was a quantitative research. The study also evaluates government policy related to sports development. Therefore, this study also includes an evaluative research. These samples included 270 people from three districts. The sampling technique used was cluster sampling. The instruments used were questionnaire and also a set of protocols of Multi Stage Fitness Test to test the
\end{abstract}


physical fitness data of the public. The results showed that (1) the index of open space in Jambi city was 0,364 , higher than the index of open space nationwide $(0,266),(2)$ The index of sport Human Resources was 0.00057 , lower than national human resources index (0.099), (3) the results of the public participation index was 0.57 , is higher than the national participation index $(0.422)$, (4) the value of physical fitness index was 0.340 , was higher than the national index $(0.335), 5)$ the value of sports development index of Jambi City was 0,318. The result of all is the norm to categorize SDI index of Jambi City was still in the poor categories because of the SDI index include the open space, human resources, participation sports and physical fitness Jambi City is 0,318 was a value between 0 to 0.499 . This means that the Jambi city sports development need to be considered and addressed by goverment to promote the sport in the city of Jambi.

Keywords: Sport Development Index, Open Space, Human Resources, Participation Sports \& Physical Fitness.

\section{PENDAHULUAN}

Pembangunan merupakan sebuah usaha dan proses untuk menuju pada suatu perubahan bisa secara positif maupun negatif secara parsipatori dari keseluruhan element yang menginginkan sebuah perubahan. Keberhasilan pembangunan khususnya pembangunan manusia pada suatu daerah dapat dinilai secara parsial dengan melihat seberapa besar permasalahan yang paling mendasar di masyarakat tersebut dapat teratasi. Permasalahan-permasalahan tersebut diantaranya adalah kemiskinan, pengangguran, buta huruf, ketahanan pangan, dan penegakan demokrasi. Namun persoalannya adalah capaian pembangunan manusia secara parsial sangat bervariasi dimana beberapa aspek pembangunan tertentu berhasil dan beberapa aspek pembangunan lainnya gagal. Indeks pembangunan sebuah Kota dinilai berdasarkan Indeks Pembangunan Manusia di Kota tersebut. Indeks Pembangunan Manusia merupakan tolak ukur untuk menilai bagaimana pembangunan di suatu daerah apakah maju ataupun mundur. Seperti Indeks Pembangunan Manusia yang dimiliki oleh Kota Jambi. Kota Jambi termasuk kota yang luas dikarenakan merupakan ibukota Provinsi dan pusat keramaian. Indeks Pembangunan Manusia di Kota Jambi pada tahun 2013 yaitu 77,52 dibawah Sungai Penuh yaitu 78,11. Indeks Kota Jambi pada tahun 2013 juga meningkat 0,44 dari tahun 2012. Rata-rata IPM Jambi adalah 74,35. Peningkatan yang sedikit demi sedikit namun pasti dilakukan ini merupakan imbas dari berbagai pembangunan yang dilakukan oleh Pemerintah dan juga masyarakat yang ada di Jambi.

Dalam pembangunan olahraga, hasil yang telah dicapai adalah terumuskannya konsep kebijakan yang mendukung perkembangan olahraga nasional dan pedoman mekanisme pembinaan olahraga dan kesegaran jasmani, dengan tersusunnya Rancangan Undang-undang Olahraga untuk mendukung perkembangan olahraga nasional, dan tersusunnya Sport Development Index (SDI). Sport Development Index merupakan tolak ukur untuk dapat mengetahui seberapa besar dan bagaimana Pembangunan Olahraga di suatu daerah berkembang dengan baik atau tidak. SDI merupakan buah pemikiran atas kebimbangan dari para pencetus Sport Development Index yaitu Toho Cholik Mutohir, dkk yang prihatin bahwa penentu pembangunan olahraga dari suatu daerah ditentukan dari seberapa banyak medali yang diperoleh oleh daerah tersebut. Padahal, sebuah pemikiran yang keliru jika pembangunan olahraga hanya ditentukan oleh medali tanpa memikirkan dari sudut lain. Kemudian timbul sebuah ide untuk tidak hanya mengukur pembangunan dari pendapatan medali, melainkan juga melalui aspek-aspek lain. Untuk itulah dicetuskan Sport Development Index yang dapat mengukur pembangunan olahraga di suatu daerah dengan melihat dari 4 dimensi yang meliputi Ruang Terbuka, Sumber Daya Manusia, Partisipasi Olahraga dan Kebugaran Jasmani. 
Dalam pengukuran Pembangunan Olahraga di Kota Jambi yang pertama kali dilakukan pada tahun 2004 menunjukkan bahwa indeks pembangunan olahraga di Kota Jambi sebesar 0.325 dengan indeks ruang terbuka sebesar 0.374, indeks SDM sebesar 0.134, indeks partisipasi olahraga 0.311 dan indeks kebugaran jasmani sebesar 0.479. Pembangunan olahraga di Kota Jambi mengalami penurunan. Selain dibuktikan dengan penurunan prestasi yang diperoleh di PON, ditunjukkan juga dengan penurunan dari Indeks Pembangunan Olahraga yang diukur melalui Sport Development Index yaitu pada tahun 2005, Kota Jambi hanya memperoleh indeks pembangunan olahraga sebesar 0.288 itu artinya terjadi penurunan sebesar 0.037 dari pengukuran di tahun 2004. Pengukuran indeks pembangunan olahraga di Kota Jambi pun kian merosot dengan didapatkan hasil SDI pada tahun 2006 di Kota Jambi yang hanya sebesar 0.281 .

Pembangunan olahraga di Indonesia khususnya di Kota Jambi dapat dilihat melalui 4 aspek yang terkandung dalam Sport Development Index (SDI) yaitu (1) Ruang Terbuka, (2) Sumber Daya Manusia, (3) Partisipasi Olahraga, dan (4) Kebugaran Olahraga. Keempat aspek ini akan membantu menilai bagiamana pembangunan olahraga di Kota Jambi berjalan dan berproses dari tahun ke tahun. Tinggi rendahnya indeks dari keempat dimensi SDI akan mempengaruhi pengukuran indeks pembangunan olahraga di daerah.

\section{METODE}

\section{Jenis Penelitian}

Sesuai dengan substansi dan fokus penelitian ini, yaitu kajian tentang pembangunan olahraga, dimana hasil dari pembangunan olahraga diungkapkan melalui indeks yang sajian datanya berupa angka, maka jenis penelitian ini termasuk dalam jenis penelitian kuantitatif. Substansi Sport Development Index sudah dituangkan dalam kebijakan pemerintah bidang keolahragaan, terutama terkait dengan Standar Pelayanan Minimal Keolahragaan sebagaimana tertuang dalam Peraturan Pemerintah RI Nomor 16 tahun 2007 Pasal 92, yang memberikan penjelasan operasional tentang persyaratan Standar Pelayanan Minimal Keolahragaan yang meliputi: ruang terbuka untuk berolahraga, tenaga keolahragaan atau SDM keolahragaan,partisipasi olahraga, dan tingkat kebugaran jasmani masyarakat. Oleh karena itu untuk mengevaluasi kebijakan pemerintah terkait pembangunan olahraga maka penelitian ini juga termasuk penelitian evaluatif atau penelitian evaluasi. Penelitian evaluasi menuntut persyaratan yang harus dipenuhi, yaitu adanya kriteria, tolak ukur, atau standar yang digunakan sebagai pembanding bagi data yang diperoleh, setelah data tersebut diolah dan merupakan kondisi nyata dari objek yang diteliti. Kesenjangan antara kondisi nyata dengan kondisi harapan yang dinyatakan dalam kriteria itulah yang dicari. Dari kesenjangan tersebut diperoleh gambaran apakah objek yang diteliti sudah sesuai, kurang sesuai, atau tidak sesuai dengan kriteria (Suharsimi A, 2010: 36).

\section{Populasi dan Sampel}

Teknik pengambilan sampel menggunakan stratified random sampling dengan cluster sampling (Putra S, 2014). Stratifikasi diperlukan untuk menjawab kondisi daerah dan masyarakat yang ada di Kota Jambi yang sangat heterogen. Cluster sampling digunakan untuk mewakili luas wilayah yang akan dijadikan sampling sehingga akan terwakili. Karakter dasar dari populasi yang akan digunakan adalah 1) perbedaan tingkat kemajuan suatu wilayah yaitu: maju, sedang, tertinggal. 2) perbedaan gender laki-laki dan perempuan, 3) perbedaan usia anak umur 7-12 tahun, remaja usia 13-17 tahun dan dewasa usia 18-40 tahun. Komponen cluster yang digunakan adalah kecamatan, desa/keluraan yaitu terdiri dari 11 kecamatan dan 58 kelurahan di Kota Jambi yang akan diambil 3 kecamatan,dan masingmasing kecamatan diambil 3 kelurahan dimana setiap kelurahan diambil 30 orang, dengan pembagian laki-laki dan perempuan sehingga dalam satu kecamatan jumlah sample terdapat 90 orang sehingga dari 3 kecamatan total seluruhnya yaitu 270 sampel. 


\section{Teknik Pengumpulan Data}

Data SDI menggunakan data primer dan data sekunder (Toho dan Ali, 2007: 62). Data primer terdiri dari, data partisipasi, ruang terbuka, SDM, dan kebugaran. Sedangkan data sekunder antara lain jumlah penduduk, luas wilayah, dan potensi keolahragaan. Maka dari pernyataan diatas teknik atau cara yang dilakukan untuk mengumpulkan data adalah :

1. Observasi, data yang akan dikumpulkan melalui observasi adalah data sekunder yaitu tentang luas wilayah, jumlah penduduk, dan potensi keolahragaan sebagai data kontrol, sedangkan data primer yaitu data tentang sumber daya manusia keolahragaan dan data tentang ruang terbuka.

2. Kuesioner, data yang akan dikumpulkan melalui angket ini adalah data tentang partisipasi masyarakat dalam berolahraga.

3. Tes, data yang akan dikumpulkan melalui tes adalah data tentang tingkat kebugaran jasmani masyarakat, tes yang digunakan adalah Multi Stage Fitness (MFT).

4. Interview/wawancara, digunakan untuk menggali informasi dari para narasumber yang kredibel sebagai data penguat dari data yang diobservasi. Sumber data dalam penilain ini diperoleh dari sumber atau informan yaitu dari pemerintah Kota Jambi yang terkait seperti Dinas Pendidikan Kota Jambi, Dinas Pemuda dan Olahraga Kota Jambi, BPS Kota Jambi, Kantor Kecamatan, KONI Kota Jambi, dan sumber data lain yang dianggap memungkinkan.

\section{Teknik Analisis Data}

\section{Ruang Terbuka}

Ketika ingin menghitung indeks ruang terbuka, maka yang pertama dilakukan adalah menghitung rasio luas ruang terbuka olahraga dibagi dengan jumlah penduduk yang berusia 7 tahun keatas untuk mendapatkan niai katual. Angka standar ruang terbuka adalah $3,5 \mathrm{~m}^{2}$ per orang. Artinya nilai maksimum luas ruang terbuka adalah $3,5 \mathrm{~m}^{2}$ dan nilai minimum adalah $0 \mathrm{~m}^{2}$. Setelah semua angka didapatkan kemudian dihitung dengan menggunakan rumus :

$$
\begin{aligned}
& \text { Indeks Ruang Terbuka } \\
& =\frac{\text { Nilai Aktual }- \text { Nilai Minimum }}{\text { Nilai Maksimum }- \text { Nilai Minimum }}
\end{aligned}
$$

\section{Sumber Daya Manusia}

Setelah jumlah SDM keolahragaan didapat selanjutnya menghitung indeksnya. Pertama mencari nilai aktual, yaitu nilai yang didapat dari hasil pembagian antara jumlah SDM keolahragaan dengan jumlah penduduk yang berusia diatas 7 tahun. Nilai maksimum SDM keolahragaan yang telah ditentukan dalam SDI adalah 2,08 dan nilai minumnya adalah 0,00. Setelah semua angka didapatkan kemudian dihitung dengan menggunakan rumus :

$$
\begin{aligned}
& \text { Indeks SDM } \\
& =\frac{\text { Nilai Aktual }- \text { Nilai Minimum }}{\text { Nilai Maksimum - Nilai Minimum }}
\end{aligned}
$$

\section{Indeks Partisipasi Olahraga}

Nilai aktual partisipasi diukur berdasarkan rasio antara peserta tes yang melakukan aktifitas olahraga minimal 3 kali dalam seminggu dengan jumlah sampel yang diambil pada suatu daerah. Nilai maksimum partisipasi adalah 100 sesuai dengan yang ditetapkan dalam SDI, dan nilai 
minimumnya adalah 0 . Setelah semua angka didapat kemudian dihitung dengan menggunakan rumus :

4. Kebugaran Jasmani

$$
\begin{aligned}
& \text { Indeks Partisipasi } \\
& =\frac{\text { Nilai Aktual }- \text { Nilai Minimum }}{\text { Nilai Maksimum - Nilai Minimum }}
\end{aligned}
$$

Untuk menghitung indeks kebugaran secara keseluruhan terlebih dahulu peneliti menghitung indeks kebugaran masing-masing klasifikasi usia. Nilai aktual kebugaran didapatkan berdasarkan hasil tes MFT, dengan nilai maksimum sesuai SDI yaitu 40,5 dan nilai minimum 20,1. Setelah semua angka didapat selanjutnya indeks kebugaran dihitung menggunakan rumus :

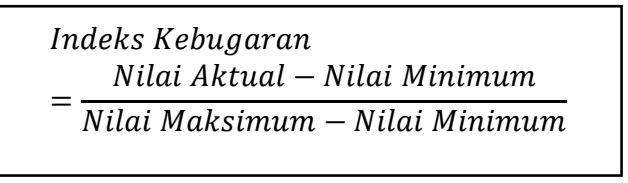

Untuk menghitung Indeks Kebugaran Jasmani di setiap Kecamatan setelah mengetahui indeks kebugaran anak-anak, remaja dan dewasa di setiap kecamatan, maka digunakan rumus:

$$
\text { Indeks Kebugaran }=\frac{\text { IK Anak }- \text { anak }+(2 \times \text { IK Remaja })+\text { IK Dewasa }}{4}
$$

\section{HASIL DAN PEMBAHASAN}

\section{a. Ruang Terbuka}

Dirangkum dari penelitian yang telah dilakukan terkait dengan Ruang Terbuka Olahraga di Kota Jambi didapatkan hasil:

Tabel 4.1. Indeks Ruang Terbuka Kota Jambi

\begin{tabular}{lllll}
\hline Kota Jambi & Kec. Telanaipura & Kec. Kotabaru & Kec. Alam Barajo & SDI \\
\hline $\begin{array}{l}\text { Ruang Terbuka } \\
\text { Olahraga }\end{array}$ & 0,495 & 0,470 & 0,128 & \\
\hline
\end{tabular}

Hasil yang diperoleh dari 3 Kecamatan yang telah diteliti yakni sebesar 0,364. Indeks Ruang Terbuka di Kota Jambi ini masih termasuk dalam kategori rendah karena belum memenuhi standar ruang terbuka yang ditetapkan oleh Komite Olympiade yakni ruang terbuka di hampir setiap 3,5m² per orang.

\section{b. Sumber Daya Manusia}

Dirangkum dari penelitian yang telah dilakukan terkait dengan Sumber Daya Keolahragaan di Kota Jambi didapatkan hasil:

Tabel 4.2. Indeks Sumber Daya Manusia Keolahragaan Kota Jambi

\begin{tabular}{lllll}
\hline \multirow{2}{*}{ SDM } & Kec. Telanai & Kec. Kotabaru & Kec. A. Barajo & SDI \\
\cline { 2 - 5 } & 0,00076 & 0,00057 & 0,00040 & \\
\hline
\end{tabular}

Hasil yang diperoleh dari 3 Kecamatan yang telah diteliti yakni sebesar 0,00057. Indeks Sumber Daya Manusia Keolahragaan di Kota Jambi ini termasuk dalam kategori sangat rendah karena masih jauh dari indeks Sumber Daya Manusia Keolahragaan Nasional sebesar 0,099. 


\section{c. Partisipasi Olahraga}

Dirangkum dari penelitian yang telah dilakukan terkait dengan Partisipasi Olahraga di Kota Jambi didapatkan hasil:

Tabel 4. 3. Indeks Partisipasi Olahraga di Kota Jambi

\begin{tabular}{lllll}
\hline Kota Jambi & Kec. Telanai & Kec. Kotabaru & Kec. A. Barajo & SDI \\
\hline Partisipasi OR & 0,533 & 0,611 & 0,566 & \\
\hline & & & & 0,57 \\
\hline
\end{tabular}

Hasil yang diperoleh dari 3 Kecamatan yang telah diteliti yakni sebesar 0,57. Indeks Partisipasi Olahraga di Kota Jambi ini termasuk dalam kategori tinggi bila dibandingkan dengan indeks Partisipasi Olahraga Nasional yang hanya sebesar 0,422.

\section{d. Kebugaran Jasmani}

Dirangkum dari penelitian yang telah dilakukan terkait dengan Kebugaran Jasmani di Kota Jambi didapatkan hasil:

Tabel 4.4. Indeks Kebugaran Jasmani di Kota Jambi

\begin{tabular}{lllll}
\hline Kota Jambi & Kec. Telanai & Kec. Kotabaru & Kec. Alam Barajo & SDI \\
\hline Kebugaran jasmani & 0,308 & 0,29 & 0,424 & \\
\hline & & & & 0,340 \\
\hline
\end{tabular}

Hasil yang diperoleh dari 3 Kecamatan yang telah diteliti yakni sebesar 0,340. Indeks Kebugaran Jasmani di Kota Jambi ini termasuk dalam kategori sedikit lebih tinggi bila dibandingkan dengan indeks Kebugaran Jasmani Olahraga Nasional yang hanya sebesar 0,335.

Tolak ukur kemajuan pembangunan olahraga di kota Jambi dapat dilihat dari 4 indikator yaitu ketersediaan ruang terbuka olahraga, SDM keolahragaan yang memadai, tingginya partisispasi masyarakat untuk melakukan aktifitas olahraga, dan tingginya tingkat kebugaran jasmani masyarakatnya. Dari keempat indikator inilah kemudian akan dihitung untuk mendapatkan nilai indeks pembangunan olahraga Kota Jambi. Dari hasil nilai indeks yang didapatkan dari 3 kecamatan yang menjadi area sampel yaitu kecamatan Telanaipura, kecamatan Kotabaru dan kecamatan Alam Barajo, maka nilai indeks pembangunan olahraga Kota Jambi dapat dilihat dalam diagram berikut: 


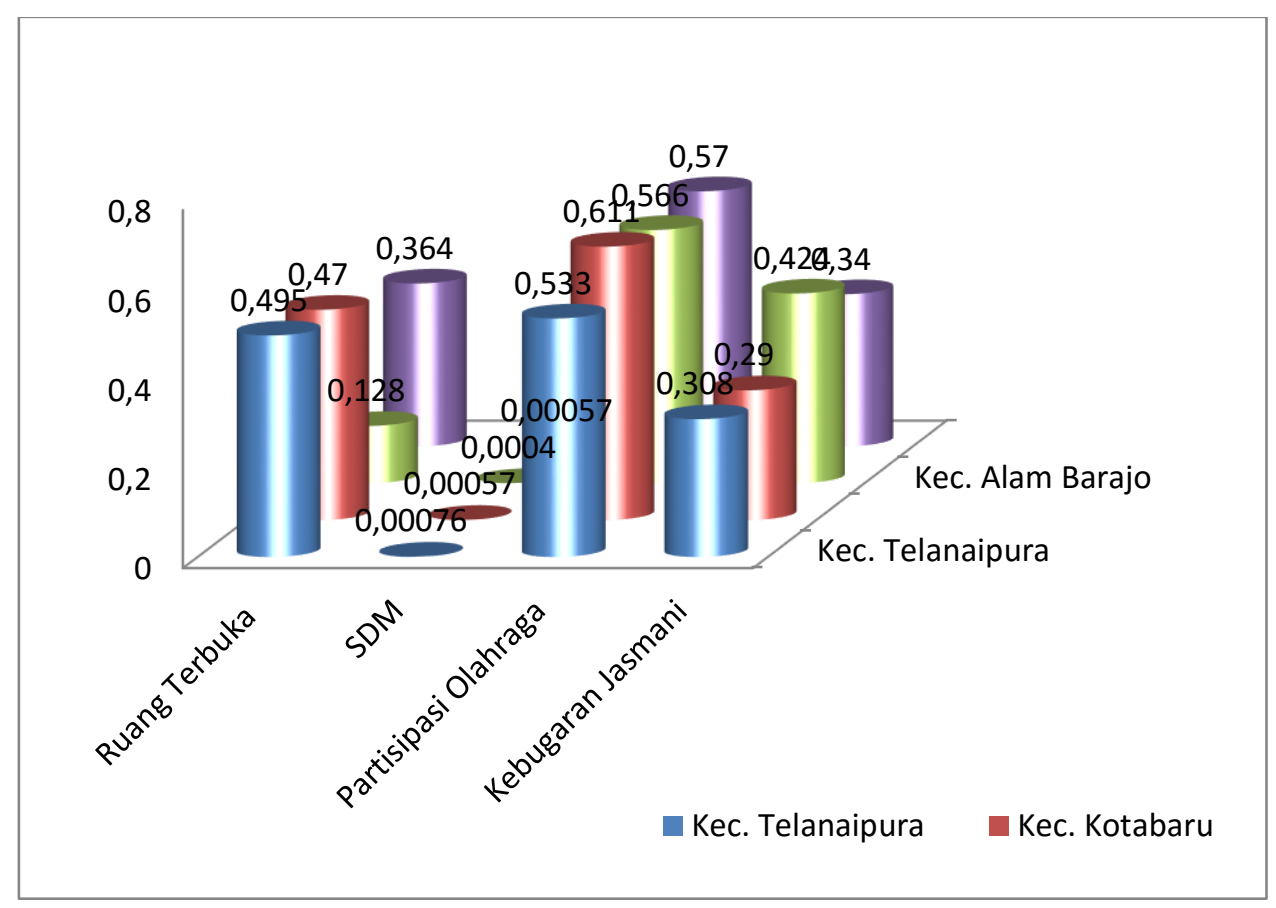

Gambar 4.1. Grafik 4 Indikator SDI Kota Jambi

Indeks Pembangunan Olahraga Kota Jambi

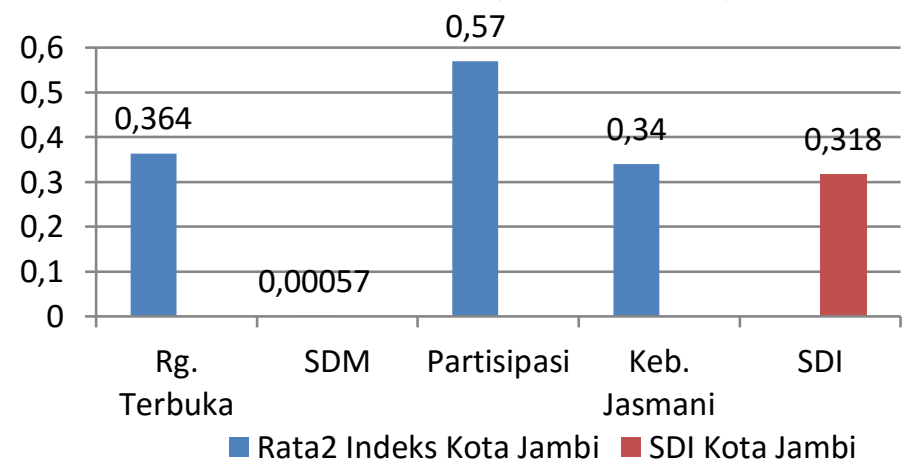

Gambar 4.2. Grafik rata-rata Indeks Pembangunan Olahraga (SDI) Kota Jambi

Diagram diatas menunjukkan perbandingan nilai Indeks dari 3 kecamatan yang menjadi area sampling untuk menentukan nilai indeks pembangunan olahraga Kota Jambi. Dari diagram ini kemudian hasil indeks akan dipaparkan dalam bentuk tabel sebagai berikut:

Tabel 4.5. SDI Kota Jambi

\begin{tabular}{lccccc}
\hline Kota Jambi & $\begin{array}{c}\text { Indeks } \\
\text { Ruang } \\
\text { Terbuka }\end{array}$ & $\begin{array}{c}\text { Indeks } \\
\text { SDM }\end{array}$ & $\begin{array}{c}\text { Indeks } \\
\text { Partisipas } \\
\text { i }\end{array}$ & $\begin{array}{c}\text { Indeks } \\
\text { Kebugaran }\end{array}$ & SDI \\
\hline Kec. Telanai & 0,495 & 0,00076 & 0,533 & 0,308 & 0,334 \\
Kec. Kotabaru & 0,470 & 0,00057 & 0,611 & 0,29 & 0,342 \\
Kec. A. Barajo & 0,128 & 0,00040 & 0,566 & 0,424 & 0,279 \\
& 0,364 & 0,00057 & 0,57 & 0,340 & $\mathbf{0 , 3 1 8}$ \\
\hline
\end{tabular}


Dari tabel diatas maka dapat disimpulkan bahwa nilai indeks pembangunan olahraga Kota Jambi adalah 0,318 . Nilai indeks ini menunjukkan bahwa pembangunan olahraga di kota Jambi masih berada pada kategori Rendah sesuai dengan norma SDI yang telah ada. Indeks ruang terbuka yang diperoleh hanya sebesar 0,364 , jauh dari standar normal yang ditetapkan yakni terdapat ruang terbuka sebesar 3,5m untuk tiap orang. Namun, perolehan indeks ruang terbuka Kota Jambi ini berada di atas perolehan indek ruang terbuka nasional yang hanya sebesar 0,266 . Untuk indeks sumber daya manusia olahraga, Kota Jambi memperoleh nilai sebesar 0,00057. Pendapatan ini sangat jauh dari yang diharapkan, perolehan nasional adalah sebesar 0,099. Hal ini menegaskan bahwa Kota Jambi masih sangat memerlukan sumber daya manusia olahraga yang akan terlibat untuk dapat mengembangkan dan memajukan potensi olahraga yang ada di Kota Jambi, diperlukan pula campur tangan keterlibatan dari Pemerintah untuk dapat memberikan fasilitas yang diperlukan, dan membantu para pelaku olahraga untuk dapat mempertahankan eksistensi olahraga di Kota Jambi.

Indeks partisipasi olahraga yang diperoleh Kota Jambi adalah sebesar 0,57, nilai ini lebih besar dibandingkan dengan perolehan indeks partisipasi nasional yang hanya memperoleh 0,422 . Ini menandakan bahwa masyarakat Kota Jambi memiliki kesadaran untuk berolahraga yang baik, namun belum sepenuhnya di fasilitasi dengan baik oleh ketersediaan ruang terbuka yang dapat dimanfaatkan. Sedangkan untuk perolehan indeks kebugaran jasmani, Kota Jambi memperoleh nilai 0,340 yang sedikit lebih tinggi dari perolehan indeks kebugaran jasmani yakni 0,335. Perolehan indeks SDI Kota Jambi keseluruhan ditinjau dari ruang terbuka, sumber daya manusia, partisipasi olahraga dan kebugaran jasmani adalah sebesar 0,318. Nilai yang didapat ini lebih besar dari pada nilai indeks SDI nasional tahun 2006 yang hanya sebesar 0,280, namun begitu jika dilihat dari norma SDI yang berlaku bahwa indeks SDI Kota Jambi masih berada dalam kategori rendah karena masih dalam rentang indeks 0-0,499. Hal ini menegaskan bahwa pembangunan olahraga Kota Jambi masih jauh dari kata maju, banyak hal-hal yang perlu diperhatikan dan dibenahi oleh Pemerintah untuk memajukan olahraga di Kota Jambi. Dimensi yang perlu perhatian khusus adalah dimensi Sumber Daya Manusia, karena dengan perolehan yang amat kecil tersebut menyebabkan tidak tercakupinya dengan baik kebutuhan tenaga keolahragaan di Kota Jambi untuk dapat membangun olahraga kearah lebih baik,baik dengan meningkatkan prestasi dan meningkatkan kualitas dimensi-dimensi yang merupakan indikator pembangunan olahraga.

\section{KESIMPULAN}

Berdasarkan permasalahan dan tujuan yang dipaparkan dalam penelitian ini, kemudian dikaitkan dengan hasil temuan penelitian dan pembahasannya, maka secara garis besar dapat di buat beberapa kesimpulan sebagai berikut:

1. Indeks ruang terbuka kecamatan Telanaipura merupakan indeks yang paling tinggi jika dibandingkan 2 kecamatan lainnya yakni sebesar 0,495. Kecamatan Kotabaru diurutan kedua dengan nilai indeks sebesar 0,470. Sedangkan kecamatan Alam Barajo memiliki indeks ruang terbuka yang paling rendah yakni hanya sebesar 0,128. Dari nilai indeks ketiga kecamatan ini maka didapatlah nilai indeks ruang terbuka Kota Jambi adalah 0,364. Nilai indeks ini lebih tinggi dibandingkan nilai indeks ruang terbuka nasional yang hanya 0,266 . Artinya bahwa indeks ruang terbuka olahraga untuk masyarakat di kota Jambi sudah cukup memadai ketersediaannya.

2. Indeks Sumber daya manusia keolahragaan kecamatan Telanaipura adalah 0.00076 lebih tinggi dibandingkan 2 kecamatan lainnya walaupun nilai indeks 2 kecamatan lainnya tidak jauh berbeda. Kecamatan Kotabarudengan nilai 0,00057 dan kecamatan Alam Barajo sebesar 0,00040. Dari nilai indeks SDM keolahragaan ketiga kecamatan inilah yang kemudian dihitung dan didapatlah nilai indeks SDM keolahragaan Kota Jambi adalah 0,00057. Nilai indeks ini masih sangat jauh dibawah 
indeks SDM nasional yaitu 0,099. Artinya bahwa jumlah dan kualitas SDM keolahragaan di Kota Jambi masih belum memadai bahkan masih sangat kurang.

3. Indeks partisipasi masyarakat kecamatan Kotabaru adalah yang tertinggi dengan 0,611. Kecamatan Alam Barajo berada dibawahnya dengan nilai indeks 0,566. Sedangkan nilai indeks partisipasi yang paling rendah adalah kecamatan Telanaipura yaitu 0,533 tidak jauh berbeda dengan indeks Kecamatan Alam Barajo. Dari ketiga hasil indeks partisipasi ini kemudian dijumlahkan dan didapatlah hasil indeks partisipasi masyarakat Kota Jambi yaitu 0,57. Nilai indeks ini lebih tinggi dibandingkan nilai indeks partisipasi nasional yaitu 0,422. Artinya nilai indeks partisipasi ini menunjukkan bahwa tingkat partisispasi masyarakat Kota Jambi untuk beraktifitas olahraga cukup tinggi.

4. Indeks kebugaran jasmani masyarakat kecamatan Alam Barajo adalah yang tertinggi dengan nilai indeks 0,424. Kacamatan Telanaipura berada dibawahnya dengan nilai indeks 0,308, sedangkan kecamatan Kotabaru menjadi yang paling rendah dengan nilai indeks 0,29. Hasil nilai indeks kebugaran dari 3 kecamatan ini kemudian dihitung untuk mendapatkan indeks kebugaran jasmani masyarakat Kota Jambi. dari hasil perhitungan itu maka didapatlah nilai indeks kebugaran jasmani Kota Jambi yaitu 0,340. Nilai indeks ini termasuk tinggi jika dibandingkan dengan indeks kebugaran nasional yaitu 0,335. Artinya bahwa tingkat kebugaran jasmani masyarakat kota Jambi termasuk tinggi.

5. Indeks pembangunan Olahraga (SDI) kecamatan Kotabaru lebih tinggi dibandingkan 2 kecamatan lainnya dengan nilai indeks 0,342 . Kecamatan Telanaipura berada dibawahnya dengan nilai indeks 0,334, sedangkan kecamatan Alam Barajo memiliki nilai indeks pembangunan olahraga yang sangat rendah yaitu 0,279 . Hasil nilai indeks pembangunan olahraga dari 3 kecamatan ini kemudian dihitung dan didapatlah nilai indeks pembangunan olahraga (SDI) Kota Jambi yaitu 0,318. Nilai indeks SDI Kota Jambi ini lebih tinggi dari nilai indeks SDI Nasional tahun 2006 dengan nilai indeks 0,280. Namun jika dilihat dari norma SDI untuk mengkategorikan indeks SDI, maka nilai indeks SDI Kota Jambi masih berada pada ketegori rendah karena indeksnya masih berada diantara nilai 0-0,499. Artinya bahwa pembangunan olahraga kota Jambi masih jauh dari kata maju, banyak hal yang perlu diperhatikan dan dibenahi oleh pemerintah kota untuk memajukan olahraga di kota Jambi. dari keempat indikator indeks SDM adalah yang paling rendah hanya 0,00040 , artinya bahwa ketersediaan SDM keolahragaan seperti guru/dosen olaharaga,wasit, pelatih dan instruktur olahraga masih sangat kurang jumlahnya di kota Jambi. Pemerintah kota harus bekerja sama dengan DISPORA, Dinas Pendidikan Kota, dan KONI dalam membuat kebijakan untuk meningkatkan indeks SDM keolahragaan Kota Jambi. agar jumlah dan kualitas SDM Keolahragan kota Jambi tidak tertinggal oleh daerah lainnya. Karena dengan banyaknya SDM keolahragaan akan dapat membantu terciptanya pembangunan olahraga yang lebih baik dan lebih maju.

\section{DAFTAR PUSTAKA}

Agus Kristiyanto. 2012. Pembangunan Olahraga Untuk Kesejahteraan Rakyat dan Kejayaan Bangsa. Yuma Pustaka. Surakarta

Ali. 2014. Pengertian Pembangunan Menurut Pakar.www.pengertianpakar.com

Ambar Teguh Sulistiyani. 2009. Manajemen Sumber Daya Manusia. Yogyakarta: Graha Ilmu

Arif Budiman. 1995. Teori Pembangunan Dunia Ketiga. Jakarta: PT. Gramedia Pustaka Utama

Aspen Institute. 2014. Sport For All. Play For Life. A Playbook to Get Everykid in The Game. Aspen Institute Sports and Society Program, Washington D.C. U.S

Aulia Agustina. Indikator Pembangunan. http:// academia.edu/9601958/indikator-pembangunan

Badan Pusat Statistik Kota Jambi. 2013. Kecamatan Dalam 2013. (http://www.bps.Kota Jambi.go.id/html.).

Badan Pusat Statistik Kota Jambi. 2013. Index Pembangunan Manusia. (http://www.bps.Kota jambi.go.id/html.). 
Deptan. Indikator Keberhasilan Pembangunan. http://ppmkp.bpp.sdmp.deptan.go.id/ index.php/artikel/kepemimpinan-dan-manajemen/75-indikator-keberhasilanpembangunan $/ \mathrm{html}$

Didin Budiman. Evaluasi Penjas. www.file.upi.edu. UPI. Bandung

Dini Rosdiani. 2013. Dinamika Olahraga dan Pengembangan Nilai. Alfabeta. Bandung

Fitriani Ulinda. 2015. KONI Provinsi Jambi dan Tantangannya. Media Jambi.com. di akses pada 29 Mei 201620.00 WIB

Hamdi M. 2014. Kebijakan Publik ; Proses, Analisis, dan Partisipasi. Bogor : Ghalia Indonesia.

Husdarta. 2011. Manajemen Pendidikan Jasmani. Alfabeta. Bandun

Isbandi Rukminto Adi. 2007. Perencanaan Patisipatoris Berbasis Aset Komunitas: dari Pemikiran Menuju Penerapan. Depok: Fisip UI Press

Mikkelsen, Britha. 1999. Metode Penelitian Partisipatoris dan Upaya-upaya Pemberdayaan: Sebuah Buku Pegangan Bagi Para Praktisi Lapangan. Jakarta: Yayasan Obor Indonesia

Mokhammad Firdaus. 2015. Kebijakan Pemerintah Tentang Pembinaan Olahraga Rekreasi di Kota Surakarta (Evaluasi Tentang Kelayakan Sumber Daya Manusia, Ketersediaan Fasilitas Oolahraga dan Bntuan Teknis dalam Olahraga Rekreasi), Tesis. Pascasarjaana. UNS. Surakarta.

Nurhasan. 2001. Tes Pengukuran dalam Pendidikan Jasmani. Jakarta : Depdiknas.

Noor Isran. 2013. Daerah Maju Indonesia Maju; Strategi Pembangunan yang Mensejahterakan dan Berkeadilan. Grafindo.

Parsiyo. 2014. Indikator Keberhasilan Pembangunan. Dikutip dari laman resmi Kementrian Pertanian Pusat Pelatihan Manajemen dan Kepemimpinan Pertanian. Ppmkp.bppsdmp.deptan.go.id. diakses pasa 20 Januari 2016

Pollock, Michael.L., Feigenbaum, Matthew. S., and Brechue, William. F. 1995. Excercise Prescription for Physical Fitness. American Academy of Kinesiologi and Physical Education.

Prayitno. 2009. Dasar Teori dan Praksis Pendidikan. Grasindo. Jakarta

Putra Sastaman B. 2014. Pembangunan Olahraga Kota Pontianak Provinsi Kalimantan Barat ditinjau dari Sport Development Index (Studi Evaluasi tentang, Ruang Terbuka, Sumber Daya Manusia, Partisipasi Masyarakat dan Tingkat Kebugaran Jasmani. Tesis. Pascasarjana UNS. Surakarta.

Rauf A. Hatu. 2013. Sosiologi Pembangunan. Gorontalo: Interpena Renstra KEMENPORA .20102014. Pdf .

Rusli Lutan dan Sumardianto. 2000. Filsafat Olahraga. Departemen Pendidikan dan Kebudayaan.

Sugiyanto. 2014. Filsafat Olahraga. Surakarta: UNS

Sugiyono. 2014. Memahami Penelitian Kualitatif. Bandung : Alfabeta.

Sugiyono. 2006. Metode Penelitian Pendidikan (Pendekatan Kuantitatif, Kualitatif dan R\&D). Alfabeta. Bandung

Suharsimi Arikunto. 2010. Prosedur Penelitian, Suatu Pendekatan Praktik. Jakarta :RinekaCipta.

Sumaryanto. 2005. Sport Development Index sebagai Parameter dalam mengukur Pembangunan Olahraga Indonesia.Yogyakarta: makalah, Disajikan dalam rangka kegiatan FONI Di kantor PORA Pemkot Yogyakarta tanggal 24 Desember 2005.

Sutopo H.B. 2006. Metodologi Penelitian Kualitatif Dasar Teori dan Penerapannya dalam Penelitian. Surakarta : USM Semarang.

Snyder, Eldon.E. 1983. Sports-Sosial Aspects. Englewood Cliff, N.J

Syarif Moeis. 2009. Pembangunan Masyarakat Indonesia Menurut Pendekatan Teori Modernisasi dan Teori Dependensi. Disajikan dalam Makalah Diskusi Jurusan Pendidikan Sejarah FPIPS UPI Bandung. Diakses di laman file.upi.edu pada 31 Juli 2016 pkl 20.00 wib.

Tikson, Deddy T. 2005. Theory of Underdevelopment and Dependent Development of Economic in Indonesia, Malaysia, and Thailand. Ininnawa

Toho Cholik Mutohir dan Ali Maksum. 2007. Sport Development Index, Alternatif Baru Mengukur Kemajuan Pembangunan di Bidang Olahraga (Konsep, Metodologi, dan Aplikasi). PT. Indeks

Toho Cholik Mutohir dkk. 2011. Berkarakter dengan Berolahraga Berolahraga dengan Berkarakter. Surabaya : SPORT Media. 
Undang-Undang Sistem Keolahragaan Nasional. 2013. Undang-Undang Kepemudaan dan Olahraga. Fokusindo Mandiri. Bandung

Wahidmurti, Alfin Mustikawan dan Ali Ridho. 2010. Evaluasi Pembelajaran (Kompetensi dan Praktik). Nuha Litera. Yogyakarta

Wahjoedi. 2000. Tes Pengukuran dalam Pendidikan Jasmani dan Olahraga. Ujung Pandang : Singaraja.

Yeung Hoi-Cheng, dkk. 2009. Consultant study on Sport for All-Participation Patterns of Hong Kong People in Physical Activities. Community Sports Committe of The Sports Commission. Leisure and Cultural Service Department. The Chinese University of Hong Kong Department of Sports Science and Physical Education. Hong Kong. Diakses pada laman www.lcsd.gov.hk/en/sportforall/common/pdf/study_abr_082009_e.pdf 